\title{
PENGGUNAAN BUKU LUGHATI DALAM MENINGKATKAN PENGUASAAN KAIDAH NAHWIYAH SISWA MELALUI METODE TADRIBAAT
}

\author{
Shofa Musthofa Khalid dan Maman Abdurrahman \\ Pendidikan Bahasa Arab SPs UPI \\ Shofelia191015@gmail.com/mamanabdurrahman@upi.edu
}

\begin{abstract}
This study was motivated by the phenomenon of saturation and low student achievement nahwiyah student rules, more specifically related to learning strategies used. On this basis the use of Lughati researchers use as a strategy in an effort to find alternative solutions to increase the interest and enthusiasm of students in the study of learning the rules of nahwiyah. This study aimed to look for alternative learning strategies more appropriate to be applied especially in learning the rules through the use of Lughati. This study uses Classroom Action Research through 3 cycles, the object of this study is the high school students of class XI YAPI Al-Husaeni Ciparay Bandung as many as 25 people in the academic year 2015-2016. The instruments used were observation, interviews, documentation, questionnaires and tests. The results showed that tarakib sya'iah exist in Lughati are: murakab idhafi, washfi, athfi and isnadi. After testing each cycle through techniques tadribat no significant increase, namely from 54.20 to 56.00 - 65.20. That is, the Lughati could improve the mastery of the rules of the students in high school nahwiyah YAPI Al-Husaeni Ciparay Bandung.
\end{abstract}

Keywords: Lughati, tarakib sya'iah, rules nahwiyah

\section{ABSTRAK}

Studi ini dilatarbelakangi oleh adanya fenomena kejenuhan siswa dan rendahnya prestasi kaidah nahwiyah siswa, lebih khusus berkaitan dengan strategi pembelajaran yang digunakan. Atas dasar ini penggunaan buku Lughati peneliti jadikan sebagai strategi dalam upaya mencari solusi alternatif untuk dapat meningkatkan minat dan semangat mahasiswa dalam mempelajari kaidah nahwiyah. Penelitian ini bertujuan untuk mencari alternatif strategi pembelajaran yang lebih tepat untuk diterapkan khususnya dalam pembelajaran kaidah nahwiyah melalui penggunaan buku Lughati. Penelitian ini menggunakan PTK melalui 3 siklus, objek studi ini adalah siswa kelas XI SMA YAPI Al-Husaeni Ciparay Bandung sebanyak 25 orang pada tahun ajaran 2015-2016. Instrumen yang digunakan adalah observasi, wawancara, dokumentasi, angket dan tes. Hasil penelitian menunjukkan bahwa tarakib sya'iah yang ada pada buku Lughati adalah: murakab idhafi, washfi, athfi dan isnadi. Setelah dilakukan tes setiap siklus melalui teknik tadribat diperoleh rata-rata ada peningkatan signifikan, yaitu 54,20 - 56,00-65.20. Artinya, buku Lughati dapat meningkatan penguasaan terhadap kaidah nahwiyah para siswa di SMA YAPI AlHusaeni Ciparay Bandung.

Kata Kunci: Lughati, tarakib sya'iah, kaidah nahwiyah

\section{PENDAHULUAN}

Pembelajaran (instruction) adalah suatu usaha untuk membuat peserta didik belajar atau suatu kegiatan untuk membelajarkan peserta didik. Dengan kata lain, pembelajaran merupakan upaya menciptakan kondisi agar terjadi kegiatan belajar. Dalam pengertian lain, pembelajaran adalah usaha-usaha yang terencana dalam memanipulasi sumbersumber belajar agar terjadi proses belajar dalam diri peserta didik (Sadiman, dkk, 1986:7).

Dalam kegiatannya, pembelajaran memerlukan strategi dalam mewujudkan tujuan pembelajaran itu sendiri sesuai dengan materi ajarnya. Begitupun dengan pembelajaran bahasa, terlebih dalam hal ini yakni bahasa asing, termasuk pula bahasa Arab yang merupakan bahasa asing yang dipelajari di Indonesia.

Dalam pembelajaran bahasa Arab terdapat perbedaan dalam mengajarkannya antara pembelajaran penutur asli dalam hal ini orang Arab itu sendiri, serta pembelajaran bagi bukan penutur bahasa Arab itu sendiri. Lebih khusus terkait pembelajaran kaidah nahwiyah atau sejenis dengan gramatikal bahasa Arab yang memerlukan strategi yang 
tepat untuk memudahkan pembelajarannya baik bagi guru atau peserta didik.

Namun dalam pelaksanaan pembelajaran Nahwu, terdapat beberapa kesulitan yang menjadi penyebab kurang berhasilnya mahasiswa dalam menguasai materi ajar yang disampaikan. Hal ini sebagaimana yang dijelaskan Al-Khifajy (2008: 176) bahwasannya kesulitan pembelajaran Nahwu bukan pada Nahwu itu sendiri melainkan dalam startegi dan metode pengajaran yang diterapkan dalam pembelajaran.

Nasution (2012: 2) menambahkan, bahwa: Kenyataan menunjukkan tidak sedikit mahasiswa, siswa atau santri yang mempelajari bahasa Arab berkomentar: bahwa materi Nahwu merupakan materi yang paling sulit dipelajari. Penilaian ini kemudian menimbulkan image negatif terhadap bahasa Arab, dimana bahasa Arab dianggap sebagai 'momok' yang menakutkan, dan kemudian membuat banyak orang tidak simpatik mempelajari bahasa Arab.

Proses belajar mengajar yang baik hendaknya mempergunakan berbagai jenis metode mengajar secara bergantian atau saling bahu membahu satu sama lain. Masing-masing metode ada kelemahan ada pula keuntungannya. Tugas guru ialah memilih berbagai metode yang tepat untuk menciptakan proses belajar mengajar. Ketepatan penggunaan metode mengajar tersebut sangat bergantung kepada tujuan, isi proses belajar mengajar dan kegiatan belajar mengajar.

Agar ada peningkatan proses dan hasil belajar, guru harus melakukan pembaharuan dengan menyajikan pembelajaran inovatif. Menurut Suyatno (2009:6) pembelajaran inovatif adalah pembelajaran yang dikemas oleh guru yang merupakan wujud gagasan atau teknik yang dipandang baru agar mampu memfasilitasi siswa untuk memperoleh kemajuan dalam proses dan hasil belajar.

Di antara bentuk inovasi pembelajaran Bahasa Arab yang dapat dilakukan adalah penggunaan media dan metode. Penggunaan keduanya dapat menumbuhkan suasana dan hal baru dalam kegiatan pembelajaran yang dapat meningkatkan motivasi pembelajaran siswa, yaitu dengan menggunakan buku Lughati dan Metode Tadribaat.

Buku Lughah Jamilah adalah sebuah buku program belajar Bahasa Arab untuk segala tingkatan yang disusun berdasarkan penelitian mendalam tentang pengajaran Bahasa Arab yang disusun oleh pakar Bahasa Arab yang sangat kompeten dibidangnya, Bertujuan untuk memudahkan pengajaran Bahasa Arab untuk orang asing dengan memanfaatkan teknologi modern demi kemajuan (pengajaran) Bahasa Arab.

Penggunaan buku ini sebelumnya pernah dilakukan oleh Roja al-Din Hasan Zahdi Thomus dalam penelitian Tesisnya pada Program Pendidikan Universitas Gaza Palestina tahun 2002 dengan judul "Taqwim Muallimi al-Lughah al-Arabiyah li KItab Lughatuna al-Jamilah al-Muqarrar li alShafi al-Tsadis fi Falistin wa 'Alaqatuhu bi ittijahtihim Nahw al-Tahdits" dari hasil penelitian ditemukan bahwa buku Lughah Jamilah efektif dalam meningkatkan kemmapuan prestasi siswa dalam materi pelajaran bahasa Arab.

Penggunaan kata istilah "Tadribaat" setara dengan kata latihan, dan Drill dalam baha Inggris. Kata tersebut biasanya digunakan dalam pembelajaran nahwiyah. Tadribaat bertujuan untuk memperoleh pengetahuan dan keterampilan yang spesifik dan bahkan menjadi milik siswa dapat menguasai sepenuhnya (Haliimi, 2009: 25). Metode tadribaat adalah metode dalam pengajaran dengan melatih peserta didik terhadap bahan yang sudah diajarkan/berikan agar memiliki ketangkasan atau ketrampilan dari apa yang telah dipelajari. Pelatihan adalah cara untuk menggali keterampilan yang telah dipelajari siswa, dan mengkonsolidasikan dengan apa yang mereka pelajari (Rusdi, 1989: 227). Pengertian tadribaat dipersempit dengan menyederhanakan definisi menjadi tes 
yaitu penilaian yang komprehensif terhadap seorang individu atau keseluruhan usaha evaluasi program. (Arikunto, 2006: 32)

Dalam hal ini, tadribaat atau latihanlatihan soal yang diberikan setelah selesai satu pembahasan. Latihan tersebut lebih tepat dikatakan dengan tes formatif. Evaluasi formatif dimaksudkan untuk mengetahui sejauh mana siswa telah terbentuk setelah mengikuti sesuatu program tertentu.

Untuk mengatasi masalah rendahnya kemampuan siswa dalam penguasaan kaidah nahwiyah, penulis melalukan Penelitian Tindakan Kelas yang berlangsung dalam tiga siklus dengan menggunakan Metode Tadribaat dengan media buku Lughati di Kelas XI IPA 2 SMA YAPI Al-Husaeni Kab. Bandung pada Semester I Tahun Pelajaran 2015/2016 untuk memperoleh data tentang pelaksanaan kegiatan pembelajaran, kontribusi penggunaan buku Lughati tersebutdalam meningkatkan aktivitas siswa dalam belajar, dan untuk memperoleh data tentang kontribusinya terhadap peningkatan kemampuan siswa dalam Penguasaan kaidah nahwiyah.

Berdasarkan pengamatan sebelum penelitian, mayoritas siswa kelas ini menunjukkan sikap pasif dan kurang motivasi dalam belajar Bahasa Arab. Ratarata hasil belajar mereka masih di bawah KKM dan lebih rendah dibandingkan dengan rata-rata hasil belajar kelas lain. Data yang diperoleh dari hasil tes siswa Kelas XI IPA 2 pada Semester I Tahun Pelajaran 2015/2016 menunjukkan bahwa siswa yang mencapai KKM hanya berjumlah 6 dari 30 orang siswa atau $20 \%$, dengan rata-rata nilai murni seluruh siswa Kelas XI IPA 2 sebesar 40, sedangkan KKM-nya adalah 70.

Berdasarkan hal tersebut, maka dapat disimpulkan bahwa pembelajaran bagi non penutur asli memerlukan strategi pembantu dalam memudahkan pembelajaran. Dalam hal ini, buku teks atau buku ajar dan metode pembelajaran yang lebih efektif dan memiliki peran penting dalam mengatasi permasalahan pembelajaran Nahwu.

\section{METODE PENELITIAN}

Dalam penelitian ini, peneliti menggunakan metode penelitian tindakan kelas (PTK) atau classroom action research, yaitu:

"penelitian tindakan yang dilaksanakan oleh guru di dalam kelas, yang pada hakikatnya merupakan rangkaian tindakanriset-tindakan-riset dan seterusnya, yang dilakukan secara siklik, dalam rangka memecahkan masalah, sampai masalah itu terpecahkan". (Supriyadi dalam Mulyadi, 2012: 12).

Konsep pokok action research menurut Kurt Lewin dalam Supriyadi (Mulyadi, 2012:13) terdiri dari empat komponen, yaitu: (1) perencanaan (planning); (2) tindakan (acting); (3) pengamatan (observing), dan; (4) refleksi (reflecting). Hubungan keempat komponen itu dipandang sebagai satu siklus.

\section{HASIL DAN PEMBAHASAN}

Pelaksanaan penelitian dilakukan secara kolaborasi dengan sesama guru bahasa Arab di sekolah peneliti yang membantu dalam pelaksanaan observasi dan refleksi selama penelitian. Secara umum, tahapan penelitian ini terdiri atas:

a. Perencanaan, meliputi penyiapan RPP, alat observasi, bahan ajar, media pembelajaran, dan alat evaluasi untuk Kompetensi Dasar Membaca Pemahaman yakni memperoleh berbagai informasi dari wacana tulis sederhana secara tepat.

b. Tindakan, meliputi seluruh proses pembelajaran yang di dalamnya terdapat penggunaan Permainan Memasangkan Kartu.

c. Observasi, dilaksanakan bersamaan dengan proses pembelajaran meliputi: aktivitas guru dan siswa, sikap siswa, dan hasil belajar siswa.

d. Refleksi, dilakukan dengan menganalisa kegiatan pembelajaran dan dilanjutkan 
dengan menyusun rencana perbaikan pada siklus berikutnya.

Pembelajaran pada Siklus 1 merupakan perbaikan dari hasil refleksi terhadap proses pembelajaran sehari-hari setelah diketahui motivasi dan hasil belajar mereka belum optimal. Kompetensi yang akan dicapai adalah memahami wacana sederhana bahasa Arab dengan topik Di dalam Kelas (صلة) (الرحم) yang mengandung struktur Nahwiyah.

Langkah-langkah pembelajaran yang dilakukan berpedoman pada RPP yang telah disusun pada fase perencanaan. Tindakan yang dilakukan oleh peneliti dan sikap serta perilaku siswa diamati oleh observer dengan mengisi lembar pengamatan yang telah disiapkan.

Setelah penyajian materi oleh peneliti, para siswa tampak termotivasi dengan pembelajaran yang dilakukan. Soal tes dibagikan kepada setiap siswa untuk mengetahui pemahaman mereka terhadap materi yang telah dipelajari. Hal ini dapat di lihat dari hasil pengamatan dan analisis, ditemukan data sebagai berikut:

\section{a. Penggunaan Materi Lughati}

1) Kesesuaian materi dengan isi kurikulum; (a) $80 \%$ materi sesuai dengan SK yang tercantum pada silabus; (b) $80 \%$ materi sudah sesuai dengan KD yang tercantum pada RPP; (c) 80\% materi sudah sesuai dengan tujuan pembelajaran

2) Sistematika penyampaian materi; (a) $80 \%$ penyajian materi sesuai urutan; (b) $80 \%$ penyajian materi sudah mengikuti induktif dan deduktif; (c) $80 \%$ penyajian materi sudah merujuk dari konkrit ke abstrak

3) Urgensi; (a) $95 \%$ sangat dibutuhkan peserta didik; (b) $80 \%$ dapat dipalikasikan dalam pembelajaran sehari-hari; (c) 95\% diujikan dalam ujian

4) Menarik; (a) $80 \%$ materi didukung media yang sesuai; (b) $80 \%$ materi didukung metode yang menyenangkan; (c) $80 \%$ materi dapat direspon secara antusias

\section{b. Media Pembelajaran Lughati}

(1) Ketersediaan Sarana dan Media Pembelajaran; (a) 80\% sesuai dengan kebutuhan; (b) $80 \%$ tersedia untuk semua elemen sekolah; (c) $80 \%$ dapat dimanfaatkan pada saat dibutuhkan.

(2) Penempatan Media dan Sarana Pembelajaran; (a) 70\% dikelompokkan sesuai dengan jenisnya; (b) $70 \%$ mudah dijangkau; (c) $80 \%$ tersimpan dengan rapi.

(3) Kebermaknaan Media dan Sarana Pembelajaran; (a) $80 \%$ membantu kelancaran pembelajaran; (b) $80 \%$ memudahkan pemahaman pembelajar; (c) $80 \%$ sesuai dengan materi pembelajaran

(4) Kelayakan Media dan Sarana Pembelajaran; (a) $80 \%$ aman dipergunakan guru; (b) $80 \%$ aman dipergunakan siswa; (c) $80 \%$ semua sarana layak pakai.

Hasil yang diperoleh dari Tes Hasil Belajar pada Siklus 1 diketahui nilai terendah 10 , nilai tertinggi 100 , dan nilai rata-rata sebesar 54.24. Di antara 30 orang siswa yang mengikuti tes, ada 6 orang (20\%) yang telah melampaui KKM, yaitu 70. Selebihnya sebanyak $80 \%$ siswa masih memiliki nilai di bawah KKM. Apabila persentase jumlah siswa yang belum dan sudah mencapai KKM pada Siklus 1 disajikan dalam Grafik 1 di bawah ini. 


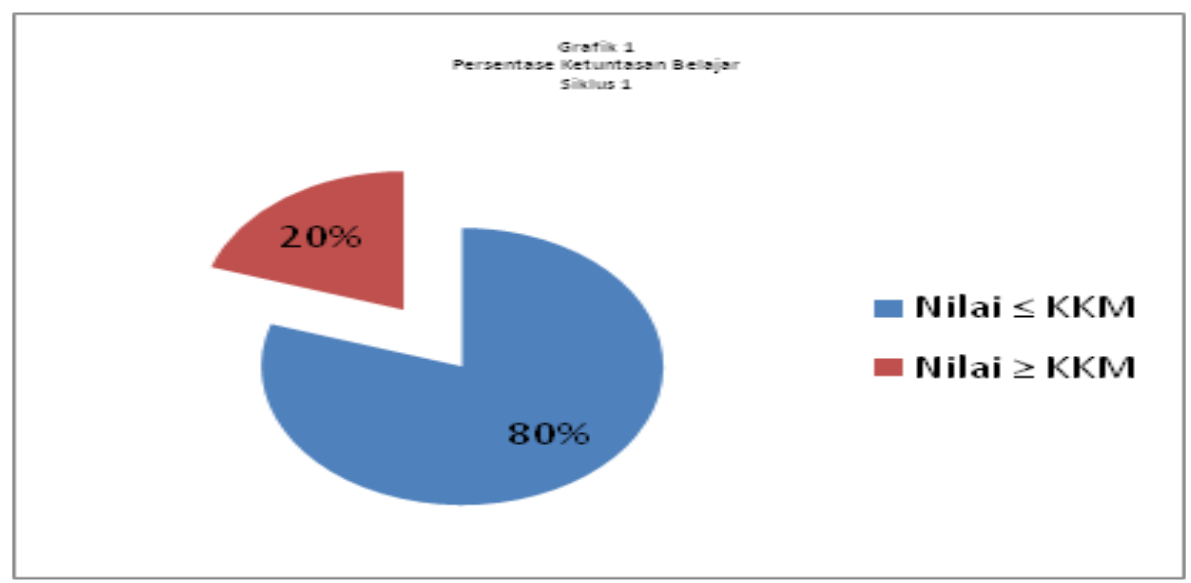

Pada pembelajaran Siklus 1, guru hanya ajar dalam pembelajaran. Hasil penelitian menggunakan buku Lughati sebagai bahan terlihat pada table 1 di bawah ini:

Tabel 1

Ringkasan Hasil Penelitian Siklus 1

\begin{tabular}{clc}
\hline No & \multicolumn{1}{c}{ Hasil Penelitian } & Jumlah \\
\hline 1 & Siswa aktif & 8 orang \\
\hline 2 & Nilai Rata-rata & 54.24 \\
\hline 3 & Presentase Ketuntasan & $20 \%$ \\
\hline
\end{tabular}

Interpretasi terhadap hasil penelitian di atas adalah bahwa pembelajaran masih perlu diperbaiki dan ditingkatkan. Hal ini dapat dilihat dari deskripsi pada Siklus 1 sebagai berikut:

1) Hasil Observasi

a) Keaktifan siswa; (1) $60 \%$ siswa aktif mencatat materi pembelajaran; (2) 45\% siswa aktif bertanya; dan (3) 50\% siswa aktif mengajukan ide

b) Perhatian siswa; (1) 50\% diam, tenang; (2) $50 \%$ terfokus pada materi; dan (3) $50 \%$ antusias

c) Kedisiplinan; (1) 90\% disiplin absensi; (2) $90 \%$ dating tepat waktu; dan (3) $90 \%$ pulang tepat waktu

d) Resitasi; (1) 70\% mengerjakan semua tugas; (2) 60\% ketepatan mengerjakan tugas sesuai waktunya; (3) $60 \%$ mengerjakan sesuai perintah

Setelah penggunaan buku lughati dalam pembelajaran yang dilakukan pada Siklus 1, peneliti dan kolaborator kemudian melakukan refleksi mengenai perubahan yang terjadi pada siswa, suasana kelas, dan guru akibat tindakan tersebut.

Perubahan yang terjadi pada siswa adalah timbulnya semangat dan motivasi mereka dalam belajar karena mereka diberi tahu sejak awal bahwa akan ada penggunaan buku Lughati oleh guru yang akan dilanjutkan dengan tes akhir. Mereka lebih focus dan serius dalam mengikuti presentasi materi oleh guru.

Guru yang biasanya lebih banyak memberikan ceramah dan menjadi sumber utama materi pelajaran dari awal sampai akhir pembelajaran, kini merasakan suasana yang berbeda. Dalam kegiatan ini guru juga berperan dalam mengarahkan dalam menjalankan tugasnya dan memantau jalannya pembelajaran terbentuk melakukan latihan dalam kelompok.

Hasil yang diperoleh dari Tes Hasil Belajar pada Siklus 2 diketahui nilai terendah 40, nilai tertinggi 100 , dan nilai rata-rata sebesar 69.28. Di antara 30 orang siswa yang mengikuti tes, ada 17 orang (56.6\%) yang telah melampaui KKM, yaitu 70. Selebihnya sebanyak $43.3 \%$ siswa masih memiliki nilai 
di bawah KKM. Apabila persentase jumlah siswa yang belum dan sudah mencapai KKM

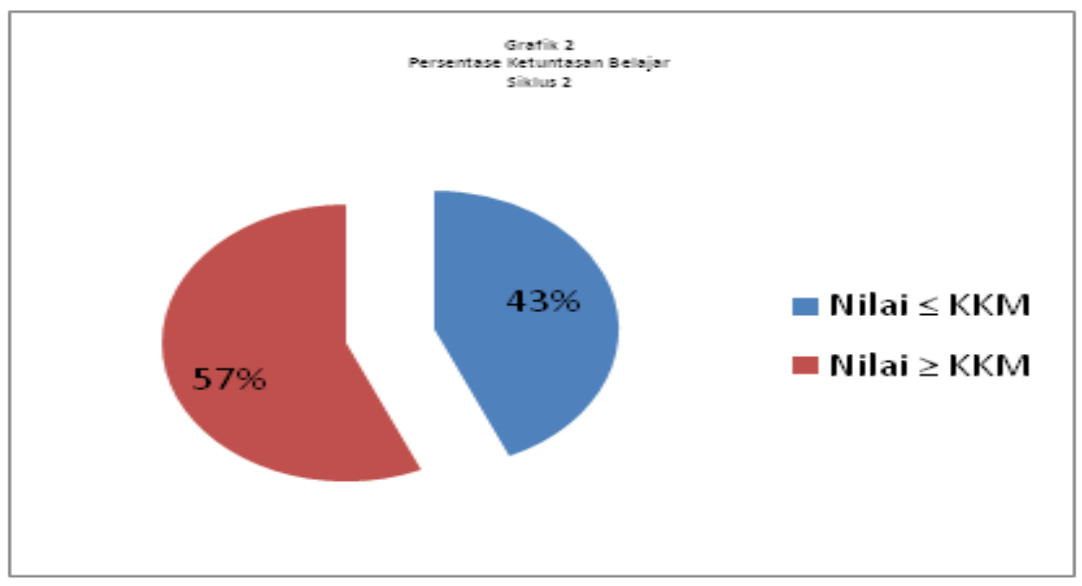

pada Siklus 1 disajikan dalam Grafik 1 di bawah ini.

Pada pembelajaran Siklus 2, guru menggunakan buku Lughati sebagai bahan

Tabel 2

Ringkasan Hasil Penelitian Siklus 2

\begin{tabular}{clc}
\hline No & \multicolumn{1}{c}{ Hasil Penelitian } & Jumlah \\
\hline 1 & Siswa aktif & 17 orang \\
\hline 2 & Nilai Rata-rata & 69.28 \\
\hline 3 & Presentase Ketuntasan & $56.6 \%$ \\
\hline
\end{tabular}

Interpretasi terhadap hasil penelitian di atas adalah bahwa pembelajaran masih perlu diperbaiki dan ditingkatkan. Hal ini dapat dilihat dari deskripsi pada Siklus 2 sebagai berikut:

1) Perencanaan; (a) RPP (terlampir); (b) Lembar Observasi (terlampir); dan (c) Instrument penilaian (terlampir)

2) Tindakan

3) Pengamatan

a) Keaktifan siswa; (1) 70\% siswa aktif mencatat materi pembelajaran; (2) 50\% siswa aktif bertanya; dan (3) 50\% siswa aktif mengajukan ide

b) Perhatian siswa; (1) 70\% diam, tenang; (2) $70 \%$ terfokus pada materi; (3) $70 \%$ antusias; (4) Kedisplinan; (1) $90 \%$ disiplin absensi; (2) 90\% dating tepat waktu; (3) $90 \%$ pulang tepat waktu

c) Resitasi; (1) $80 \%$ mengerjakan semua tugas; (2) 70\% ketepatan mengerjakan tugas sesuai waktunya; dan (3) sesuai perintah ajar dalam pembelajaran dan metode Tadribaat. Hasil penelitian terlihat pada table 2 di bawah ini:

Perubahan yang terjadi pada siswa adalah timbulnya semangat dan motivasi mereka dalam belajar karena mereka diberi tahu sejak awal bahwa akan ada penggunaan metode tadribaat oleh guru yang akan dilanjutkan dengan tes akhir. Mereka lebih focus dan serius dalam mengikuti presentasi materi oleh guru.

Guru yang biasanya lebih banyak memberikan ceramah dan menjadi sumber utama materi pelajaran dari awal sampai akhir pembelajaran, kini merasakan suasana yang berbeda. Dalam kegiatan ini guru juga berperan dalam mengarahkan dalam menjalankan tugasnya dan memantau jalannya pembelajaran terbentuk melakukan latihan dalam kelompok.

Hasil yang diperoleh dari Tes Hasil Belajar pada Siklus 3 diketahui nilai terendah 60 , nilai tertinggi 100 , dan nilai rata-rata sebesar 77.52. Di antara 30 orang siswa yang mengikuti tes, ada 27 orang $(90 \%)$ yang telah melampaui KKM, yaitu 70. Selebihnya sebanyak $10 \%$ siswa masih memiliki nilai 
di bawah KKM. Apabila persentase jumlah siswa yang belum dan sudah mencapai KKM pada Siklus 1 disajikan dalam Grafik 1 di bawah ini.

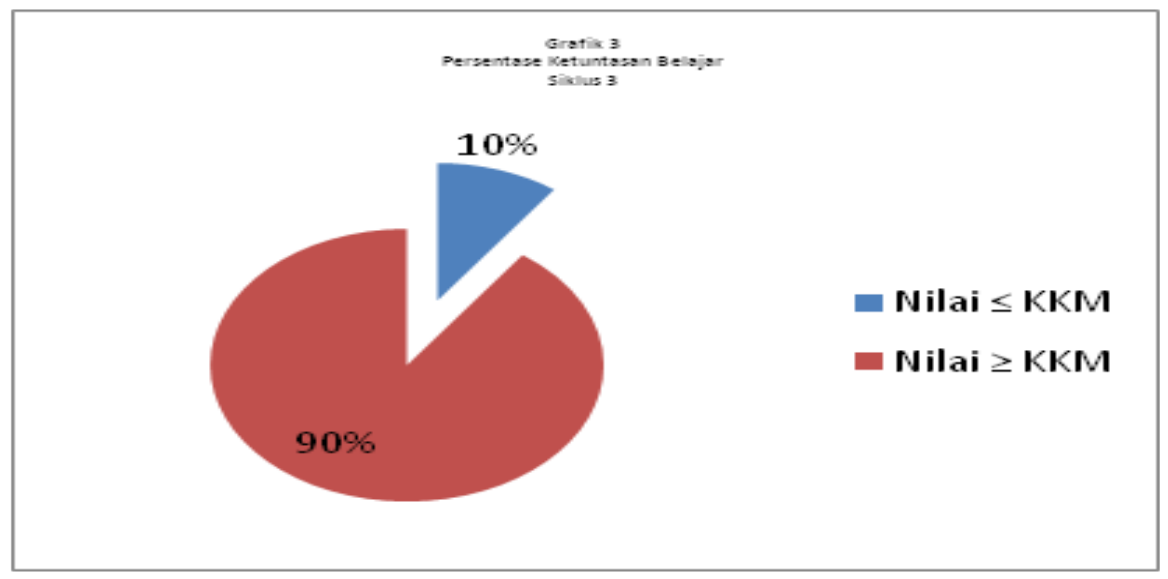

Pada pembelajaran Siklus 3, guru Tadribaat. Hasil penelitian terlihat pada table menggunakan buku Lughati sebagai bahan 3 di bawah ini: ajar dalam pembelajaran dan metode

Tabel 3

Ringkasan Hasil Penelitian Siklus 3

\begin{tabular}{clc}
\hline No & \multicolumn{1}{c}{ Hasil Penelitian } & Jumlah \\
\hline 1 & Siswa aktif & 27 orang \\
\hline 2 & Nilai Rata-rata & 77.52 \\
\hline 3 & Presentase Ketuntasan & $90 \%$ \\
\hline
\end{tabular}

Interpretasi terhadap hasil penelitian di atas adalah bahwa pembelajaran masih perlu diperbaiki dan ditingkatkan. Hal ini dapat dilihat dari deskripsi pada Siklus 3 sebagai berikut:

1) Perencanaan

a) RPP (terlampir)

b) Lembar observasi (terlampir)

c) Instrument tes (terlampir)

Dua puluh tujuh (27) dari 30 siswa atau 90\% menganggap pembelajaran bahasa Arab yang mereka ikuti dengan menggunakan buku Lughati menyenangkan. Selanjutnya dari perasaan dan anggapan positif dari siswa berimplikasi kepada asumsi bahwa penggunaan buku Lughati memudahkan dalam memahami kaidah nahwiyah.

Dari hasil resitasi yang diberikan kepada siswa, 27 dari 30 atau 90\% dari siswa mampu menyelesaikan tugas-tugas yang diberikan. Namun, dalam pelaksanaan pembelajarannya terdapat kesulitan dan kendala yang dihadapi siswa dan guru, di antara nya yaitu:
Terdapat beberapa siswa yang belum terlalu pandai membaca dan menulis bahasa Arab. Hal ini, sedikit menyulitkan guru menyampaikan materi, begitupun siswa mereka kesulitan dalam memahami secara tepat.

Waktu pembelajaran yang hanya dua jam pelajaran dengan kondisi pembelajaran bersama permasalahan sebelumnya, menghambat guru secara lebih efektif menyampaikan materi dalam pembelajaran.

Keadaan latar belakang siswa terdapat banyak beberapa siswa yang megikuti pembelajaran di pesantren, sehingga keadaan ini menciptakan kemampuan kognitif siswa yang beragam.

Dari penjabaran permasalahan di atas, dan hasil temuan evaluasi belajar siswa setelah menggunakan metode tadribat dalam buku Lughati dapat dinyatakan bahwa, terdapat pengaruh yang cukup signifikan dalam kemampuan siswa memahami kaidah 
nahwiyah yang diajarkan. Hal ini dapat dilihat dari hasil pengamatan, tindakan, pembelajaran, hasil evaluasi dari tes selama siklus dilakukan.

\section{SIMPULAN}

Merujuk pada hasil penelitian ini, dapat penulis simpulkan bahwa langkahlangkah penggunaan buku Lughati dalam meningkatkan penguasaan kaidah nahwiyah siswa melalui metode tadribaat di kelas XI
IPA 2 dimulai dengan pretest dan posttest dilanjutkan dengan siklus 1, siklus 2, dan siklus 3 dengan tahapan; perencanaan, tindakan, pengamatan, dan refleksi. Penggunaan buku Lughati dengan metode tadribaat berkontribusi positif terhadap peningkatan aktivitas siswa dan mampu meningkatkan hasil belajar siswa.

Hal ini dapat dilihat dari rata-rata hasil belajar siswa ada peningkatan signifikan dari siklus 1-3 yaitu, 54.20, 56.00, dan 65.20.

\section{DAFTAR RUJUKAN}

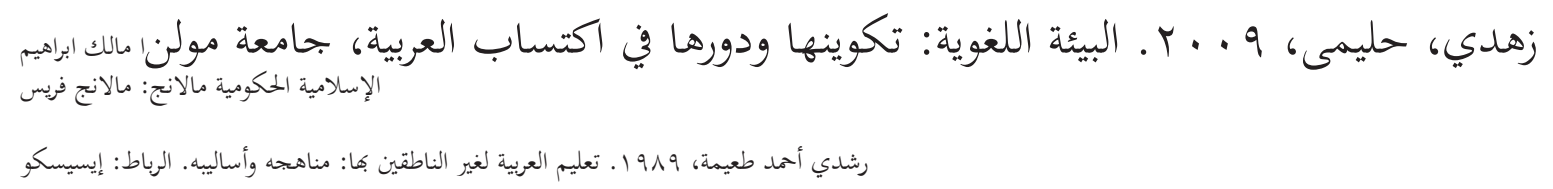

Arikunto, Suharsimi. (2006). Prosedur Penelitian Suatu Pendekatan Praktik. Jakarta : Rineka Cipta.

Al-Khifajy, A. (2008). Atsaru Ata'alum Al-Ta'awuni Fi Tahshili Thulab Ashofi Al-Tsani Mutawasithah fi Qowaid Al-Lughah Al-Arabiyah. Majalat Markaz Dirasat Al-Kuufah. 1. (8). hlm : 175-194

Grounlund, N.E. (1974). Individualizing Classroom Instruction, A Tittle in The Current Topisc in Classroom Instruction Series. New York: Macmillan Publishing.

Maspalah. 2013. Penggunaan Permainan Memasangkan Kartu Dalam Pembelajaran Bahasa Arab di SMA. 13. 51-61. (01 April 2013).

Mulyadi, Yadi. 2012. Implementasi approche globale des textes écrits dalam pembelajaran membaca teks : laporan penelitian. Bandung : Tidak diterbitkan.

Nasution, S. (2012). Eksistesi Nahwu dalam Pembelajaran Bahasa Arab dan Problematika Pembelajarannya untuk Tingkat Pemula. Jurnal Tanzimat Koopertais wil IX. (3).hlm:--

Sadiman, dkk. (1986). Media Pendidikan Pengertian, Pengembangan, dan Pemanfaatannya. Jakarta : Raja Grafindo Persada

Suyatno, N. Dan Rivai, A. 1992. Media Pengajaran. Bandung: CV. Sinar Baru Bandung

Thomus, Roja al-Din Hasan Zahdi. 2002. Taqwim Muallimi al-Lughah al-Arabiyah li KItab Lughatuna al-Jamilah al-Muqarrar li al-Shafi al-Tsadis fi Falistin wa 'Alaqatuhu bi ittijahtihim Nahw al-Tahdits. Thesis. Tidak diterbitkan. 